\title{
ADAPTIVE RESEARCH ON RICE/POTATO ROTATION MODEL (SRI FOR RICE AND MINIMUM TILLAGE METHOD FOR POTATO) IN PADDY LAND OF PHU BINH DISTRICT, THAI NGUYEN PROVINCE
}

\author{
Hoang Van Phu* , Ha Xuan Linh, Dang Hoang Ha
}

TNU - International School

\begin{tabular}{|c|c|c|}
\hline \multicolumn{2}{|c|}{ ARTICLE INFO } & ABSTRACT \\
\hline Received: & & The rice/potato rotational model (SRI-GMP model) was built and \\
\hline Revised: & $01 / 6 / 2021$ & 2018 to 2019 . The study was set up and compared conventional rice \\
\hline Published: & $02 / 6 / 2021$ & $\begin{array}{l}\text { farming (rice monoculture does not apply SRI - control); monoculture } \\
\text { of rice with SRI application; and SRI-GMP practice. Applying SRI- }\end{array}$ \\
\hline \multicolumn{2}{|l|}{ KEYWORDS } & $\begin{array}{l}\text { GPM created an ecological balance, reducing greenhouse gas } \\
\text { emissions, helping people raise awareness about environmental }\end{array}$ \\
\hline \multicolumn{2}{|c|}{ System of Rice Intensification } & protection and responding to climate change. The yield of potatoes \\
\hline \multicolumn{2}{|c|}{ Minimum tillage method } & reaching 25 tons/ha made an increase in income from 4.9 million \\
\hline \multicolumn{2}{|l|}{ Rice } & $\begin{array}{l}\text { VND/ha, } 210.5 \text { thousand VND/labor-day and } 1.09 \mathrm{VND} / \mathrm{VND} \text { for the } \\
\text { investment capital in conventional cultivation of monoculture of rice }\end{array}$ \\
\hline \multicolumn{2}{|l|}{ Potato } & into 141.3 million VND/ha, 644.4 thousand VND/ labor-day and 2.75 \\
\hline \multicolumn{2}{|c|}{ Sustainable development } & $\begin{array}{l}\text { VND/VND for the investment capital in SRI-GPM cultivation, } \\
\text { respectively. SRI-GPM created a cooperative connection between } \\
\text { farmers, companies, scientists and government, providing opportunities } \\
\text { for farmers to participate in the value chain to increase high added } \\
\text { value and stable for local people. }\end{array}$ \\
\hline
\end{tabular}

\section{NGHIÊN CỨU ÁP DƯNG MÔ HÌNH LUÂN CANH LÚA - KHOAI TÂY (SRI ĐỐI VớI LÚA VÀ PHƯƠNG PHÁP TỐI THIỄU ĐỐI VỚI KHOAI TÂY) TẠI HUYỆN PHÚ BİNH TỈNH THÁI NGUYÊN}

Hoàng Văn Phụ*, Hà Xuân Linh, Đặng Hoàng Hà

Khoa Quốc tế - ĐH Thái Nguyên

\begin{tabular}{|c|c|c|}
\hline \multicolumn{2}{|c|}{ THÔNG TIN BÀI BÁO } & \multirow{2}{*}{$\begin{array}{l}\text { TÓM TÁ̆T } \\
\text { Mô hình luân canh lúa/khoai tây theo phương pháp làm đất tối thiểu } \\
\text { (SRI-GMP) được xây dưng và triển khai tai huyên Phú Bình, tỉnh Thái }\end{array}$} \\
\hline Ngày & $3 / 4 / 2$ & \\
\hline Ngày hoàn thiện: & 10120 & Nguyên trong giai đoạn 2018 - 2019. Nghiên cứu nhằm so sánh giữa \\
\hline Ngày đăn & 1612 & $\begin{array}{l}\text { canh tác lúa thông thường (độc canh lúa không áp dụng SRI là đối } \\
\text { chứng); độc canh cây lúa có áp dụng SRI; và SRI-GMP. Âp dụng SRI- }\end{array}$ \\
\hline \multicolumn{2}{|l|}{ TÙ’ KHÓA } & $\begin{array}{l}\text { GPM thúc đẩy cân bằng sinh thái, giảm phát } t \\
\text { người dân nâng cao nhận thức về bảo vệ môi }\end{array}$ \\
\hline \multicolumn{2}{|c|}{ Hệ thống thâm canh lúa (SRI) } & \\
\hline \multicolumn{2}{|c|}{ Phương pháp làm đất tối thiểu } & 1,09 đồng/đồng \\
\hline \multicolumn{2}{|l|}{ Lúa } & công và 2,75 đồng/đồng đối với vốn \\
\hline \multicolumn{2}{|l|}{ Khoai tây } & đầu tư khi áp dụng SRI-GPM tương ứng. SRI-GPM đã tạo ra sự kết nối \\
\hline \multicolumn{2}{|l|}{ Phát triển bền vững } & $\begin{array}{l}\text { hợp tác giữa nông dân, doanh nghiệp, nhà khoa học và chính quyền, } \\
\text { tạo cơ hội cho nông dân tham gia vâo chuối giá trị nâng cao giá trị gia }\end{array}$ \\
\hline
\end{tabular}

DOI: $\underline{\text { https://doi.org/10.34238/tnu-jst.4422 }}$

\footnotetext{
*Corresponding author. Email: phuhv@tnu.edu.vn
} 


\section{Introduction}

System of Rice Intensification (SRI) and Growing Potatoes Using the Minimum Tillage Method (GPM) were recognized by the Vietnamese Government as new technical advances in 2007 and 2012 respectively. SRI helps farmers save 70-90\% of seeds, 50\% of labour for transplants, $70 \%$ of cost of plant protection (pesticides and labour), $40-50 \%$ cost of water, increase rice yield from 13-29\%, increase the efficiency of rice production by 33-35\% [1] - [5]. SRI is an ecological agriculture approach based on five principles: transplanting young seedlings, transplanting suitable sparse, restricting the use of herbicides/pesticides, properly managing water minimizing the use of chemical fertilizers and increase organic fertilizers. The GPM is also a solution for growing winter potatoes by Vietnamese farmers. Instead of traditional tillage and many chemical fertilizers, people use the minimum tillage method and the rice straws as mulching to grow potatoes. GPM helps farmers save $40 \%$ of labour to prepare the land and $70 \%$ of the harvest respectively, productivity increased $8.3 \%$, profit increased by $31 \%$ [4], [6], [7]. Besides, GPM encourages farmers not to burn straws but uses it as mulching and compost.

Therefore, both SRI and GPM encourage farmers to cultivate towards reducing chemical inputs, organic enhancement, improving the nutrition of the soil, increasing productivity and economic efficiency. Besides, these two farming methods help to motivate farmers to work in groups and development assistance in rural society. However, SRI and GPM are still only implemented individually by the farmers; there is no SRI-GPM combined rotational model in the rice cultivation system as well as the lack of scientific evidence of its benefits compared with conventional rice cultivation in monoculture (CRM). Hence, an adaptive study of SRI-GPM rotational model is necessary.

Objectives of this study are to build a model rotational SRI-GPM in paddy field with participation of the farmers and cooperation of partners (farmers - scientists - private - local government); to compare it with CRM on economic, environmental and social aspect; to promote closely cooperation in increasing value of SRI-GPM, and encouraging the conversion from conventional rice cultivation to sustainable ecological agriculture.

\section{Study approaches and methods}

\subsection{Study approach}

SRI-GPM rotational model was built to be performed by farmers according to the Farmer's Field Research Approach with the principles of Field Farmer School (FFS) and the involvement of other stakeholders. A "bottom-up" approach was used, based on the actual conditions of the farmers and with the support of scientists/experts. On this basis, a comprehensive study and holistic analysis of the model was undertaken by multiple stakeholders to make conclusions about the applicable feasibility and dissemination of models.

\subsection{Study methods}

The study was set up and compared to the following practices: (1) CRM (conventional rice monoculture, with two rice crop a year, did not apply SRI as control; (2) SRI (monoculture of rice, with two rice crops a year, applied SRI); and (3) SRI-GPM (SRI-GMP practices was the rotation system with three crops a year, including: summer rice (from July to October) - winter potatoes (November to January) - spring rice (February to June). The land of (1) and (2) in winter time were fallow. The study was carried out on an area of 10.2 hectares with the participation of a group of 62 rice farmers in Vien hamlet, Tan Duc commune, Phu Binh district, Thai Nguyen province from June 2018 to June 2019. Each participating farmer had three above rice farming practices. Khang dan variety for spring and summer rice crop; imported German's potato variety were used in the study. Farming practice of (1) was conventional; of (2) was followed by SRI principles; of (3) was followed by GPM (the minimum tillage method and use the rice straws as mulching to grow 
potatoes). The study had been designed, implemented, recorded and evaluated by the farmer group with a basic composition of women. Farmer's field research methodology with the participation of farmers was applied with the participation of the partners including farmer group; technical staffs; agricultural business sector; social organizations and local authorities.

The on-farm research method and agricultural system research with PRA tools [8] were applied in the study. Ecological research methods (Quadrad) [9] were also used to collect data and analysis of indicators on overall aspects of productivity, economic efficiency; protein in byproduct, straw management, biodiversity, environmental protection and adaptation to climate change; social capital; roles and linkages of stakeholders in the implementation and dissemination. The study had also emphasized strengthening cooperation and linking stakeholders including farmers, scientists/technicians, private enterprises and local authorities to create value-added for the products, to provide a practical basis for expansion and conversion towards sustainable agricultural ecology in rice land. The study had also tested an approach "Public - Private Partnerships" or "Linkage of 4 partners: Farmers - Technicians/Scientists Private sector - Local authorities" in technology transfer, agricultural transformation as well as sustainable rural development in the context of social and climate change in Vietnam. The open public dialogue between the partners concerned had been made to enhance their participation in the deployment of the study.

\section{Findings and discussion}

\subsection{Characteristics of the SRI - GMP model and condition of application}

In the Northern area of Vietnam, rice cultivation with 2 crops of spring rice and summer rice has existed for a long time. The advantage of this cultivation is that it is easy to do because people have accumulated experience in rice production for a long time. However, this farming is rice monoculture mainly based on concept "higher inputs to get higher outputs" that led to the overuse of chemical inputs to increase rice productivity to address these issues: food security, land exploitation and biodiversity reduction. Paddy land is also suitable for potato in period from November to February of next year. Planting potato in winter crop will increase efficiency of land use and it is easier to implement crop rotation and limit monoculture.

SRI - GMP is a rotational pattern on rice land between semi-aquatic plants (rice) and terrestrial plants (potato). It is still based on two rice crops in the year, but the winter crop is added:

Summer rice (June-October) - Winter potato (November - January)

- Spring rice (February - June)

The addition of potato in cropping structure on paddy land does not create competition both light and nutrients. SRI-GPM will take advantage of land breaks between two rice crops, harnessing all the sunlight energy shedding on an area unit throughout the year. The photosynthesis of chloroplast in the stems, leaves of rice and potatoes look like a solar panels of carbon fixing owner whole year, it does not require high technique, has low cost, low level of labor that farmers can also afford to do it. SRI-GPM utilizes the advantages that pre-crop provided good condition for the following crop (utilizing rice straw for potato cultivation) that improve economic efficiency of land area without damaging soil nutrients, minimizing the negative impact of monoculture on environment, and reducing the effects of climate change.

\subsection{Analysis of SRI - GPM model}

\subsubsection{Productivity and economic efficiency}

- Productivity: By adding one more potato crop plus with the application of SRI and GPM, the advantages of the model were demonstrated in the economic productivity shown in Table 1. In the same area of land in a year, SRI yielded 7\% higher than non-SRI practice. At the same time, if applied GPM, farmer harvested 18.5 tons of potatoes. 
Table 1. Comparison of the productivity of the different farming methods $(\mathrm{kg} / \mathrm{ha})$

\begin{tabular}{lccccc}
\hline \multirow{1}{*}{ Mode of cultivation } & \multicolumn{2}{c}{ Rice yield (paddy) } & \multicolumn{1}{c}{ Potato } \\
\cline { 2 - 6 } & $\begin{array}{c}\text { Summer rice } \\
\text { crop (2018) }\end{array}$ & $\begin{array}{c}\text { Spring rice } \\
\text { crop (2019) }\end{array}$ & Whole year & \% & Winter crop \\
\hline $\begin{array}{l}\text { Control (Monoculture 2 rice crops a year } \\
\text { does not apply SRI) }\end{array}$ & $5,041.4$ & $5,394.3$ & $10,435.7$ & 100.0 & - \\
\hline $\begin{array}{l}\text { SRI (Monoculture 2 rice crops with SRI } \\
\text { application) }\end{array}$ & $5,394.3$ & $5,771.9$ & $11,166.2$ & 107.0 & - \\
\hline $\begin{array}{l}\text { SRI-GPM (SRI summer rice - Winter } \\
\text { potatoes - SRI spring rice) }\end{array}$ & $5,394.3$ & $5,825.8$ & $11,220.1$ & 107.5 & $\begin{array}{c}18,503.6 \\
\text { (fresh tuber) }\end{array}$ \\
\hline
\end{tabular}

- Economic efficiency: As shown in Table 2, comparing to conventional rice cultivation (control), applying SRI production costs were 95\% (saving seed, medicine, spraying) and income increased by $269 \%$, and those were $186 \%$ and $1,463 \%$ respectively when both SRI and GPM were applied. Analysis efficiency of labor investment showed that while the price of rent labor was 160 thousand $\mathrm{VND} /$ labor, investment of labor in conventional rice cultivation reached 210.5 thousand VND/man-day, while applying SRI the value of a man-day increased to 295.5 thousand VND, and when SRI-GPM was applied, that increased to 406.1 thousand VND/man-day. About effectiveness of investment capital, in conventional rice cultivation, 1 VND investment after one year created 1.09 VND. When SRI was used, it increased to 1.27 VND and applying the SRIGPM reached 1.89 VND. Thus, SRI-GPM contributed to the increase of income, labor productivity and capital investment efficiency; this result is similar to those of [5], [10], [11].

Table 2. Analysis of the economic efficiency of the different farming methods

\begin{tabular}{lccc} 
& & \multicolumn{2}{c}{ Unit: thousand VND } \\
\hline Items & Control & SRI & SRI-GPM \\
\hline Revenue & $\mathbf{7 3 , 2 3 4 . 5}$ & $\mathbf{7 8 , 3 6 0 . 9}$ & $\mathbf{1 9 9 , 0 1 2 . 9}$ \\
$\%$ & 100.0 & 107.0 & 272.0 \\
$-\quad$ Paddy & $73,234.5$ & $78,360.9$ & $78,739.5$ \\
$-\quad$ Potato & & & 120.273 .4 \\
\hline Expenditure & $\mathbf{6 8 , 3 3 0 . 9}$ & $\mathbf{6 5 , 1 9 0 . 1}$ & $\mathbf{1 2 7 , 2 6 0 . 2}$ \\
$\% \quad$ Materials & 100.0 & 95.0 & 186.0 \\
$-\quad 52.779 .7$ & 49.638 .9 & 80.606 .6 \\
$-\quad$ Labor & $15,551.2$ & $15,551.2$ & $46,653.6$ \\
\hline Revenue - Expenditure & $\mathbf{4 , 9 0 3 . 6}$ & $\mathbf{1 3 , 1 7 0 . 8}$ & $\mathbf{7 1 , 7 5 2 . 7}$ \\
$\%$ & 100.0 & 269.0 & $1,463.0$ \\
Efficiency of labor investment (thousand VND/ labor) & 210.5 & 295.5 & 406.1 \\
Efficiency of investment capital (VND/VND) & 1.09 & 1.27 & 1.89 \\
\hline
\end{tabular}

\subsubsection{Environmental protection and response to climate change}

- Straw management: In the SRI - GPM model, adding a potato crop increased the photosynthetic time of the crops per unit area, generated $50 \%$ more biomass than the traditional one. In addition to the economic products, in which paddy and potato (tubers) increased, the organic matter of the model also reached more than 6.9 tons/ha/year of dry potato stems and leaves $(50.0 \%$ more than the conventional cultivation). With conventional cultivation, 14.5 tons/ha/year of rice straw (including 0.49 ton/ha/year protein in rice straw) was usually lost by burning rice straw in the field. When SRI - GPM was used, organic nutrients were retained for the next crop, contributing to soil improvement, reducing input costs in potato cultivation and spring crop in the next year (Table 3 ). 
Table 3. Estimated dry weight of crops in the different farming methods

\begin{tabular}{lccc}
\hline \multicolumn{1}{c}{ Items } & Control & SRI & SRI-GPM \\
\hline Total biomass (dry) (ton/ha/year) & 25.0 & 26.0 & 37.5 \\
$\%$ & 100.0 & 104.0 & 150.0 \\
Inside: Economic products & 10.5 (paddy) & 11.2 (paddy) & 11.2 (paddy) and \\
(dry paddy + potatoes) (ton/ha/year) & & 4.6 (potatoes) \\
Organic by-products (dry) (ton/ha/year) & 14.5 (straw) & 14.8 (straw) & 14.8 (straw) and \\
\% by-products & 100.0 & 102.1 & 150.7 \\
Protein in by-products (ton/ha/year) & 0.49 & 0.65 & 0.78 \\
\hline
\end{tabular}

- Weeds and pests: According to the farmers' assessment of the evolution of weeds and rice pests, there had been a marked change in the different types of rice cultivation.

Weeds: CRM used herbicides, therefore, the quantity of weeds was less both in density and species, especially the 2 cotyledons grass were killed by herbicides. However, with Echinochloa crus-galli $L$., the most dangerous grass affecting the yield of rice, there was no obvious difference. While the type and number of weeds at the branching stage of SRI cultivation was higher than that of conventional cultivation, harm of weeds to rice was unremarkable. With changes in weeding practices such as weeding with hand tools at 10 days early after transplanting, weeds had been killed since germination. At the same time, weeding and stirring mud had created good and rich $\mathrm{O}_{2}$ conditions for rice to make stronger growth to be able to compete for nutrition and light with weeds. The superiority of the SRI-GPM was evident in weed control. A terrestrial crop (potato) alternating between the two rice crops could destroy the weed seeds of the species such as Echinochloa crus-galli L., Leptochloa chinensis L., Fimbristyis miliacea L., Enydra fluctuans lour L., Eclita alba L.. Grass species 2 cotyledons such as Sphaeranthus africanus L., Spilanthes paniculata wall L., Monochoria vaginnalis burm F.,... Farmers said they were always concerned about weeds, but this worry had been resolved when potato crops were planted.

Golden snail: There were significant differences in the number of golden snails among studied farming types. SRI-GPM showed the advantage of controlling this pest. Due to soil preparation and weeding for potatoes, golden snails from the summer rice crop were completely destroyed. Farmers were no longer concerned about this pest in the spring rice crop after planting potatoes.

Insects: Among the insect species harming rice in the spring crop, Nilaparvata lugens stal L. was agent to care of. There were obvious differences in this harmful insect among various practices of rice cultivation. Farming under SRI and especially SRI-GMP, the harmful effect of Nilaparvata lugens stal L. had decreased markedly. Probably not using herbicides and reducing periodic spraying of pesticides increased natural enemies (spiders, bees) which killed the eggs and the worms of Nilaparvata lugens stal L., and reduced the density of Nilaparvata lugens stal $L$. throughout the rice crop. For other insect pests such as Stenchaetothrips biformis bagnall L., Scirpophaga incertulas walker L., Medinalis guenee L., there was no difference between the various ways of farming.

Disease: Yellow roots in spring rice crop did not appear in the SRI-GPM, meanwhile, it still occurred in some fields which were difficult to drain. Early weeding and stirring mud plus with the texture of the soil which changed as more potatoes were planted made the soil spongier, creating conditions for toxic gas to escape, causing less damage to the root system. Diseases such as Rhizoctonia solani kuhn L. and Pirycularia oryzae cav L. were also reduced significantly in the SRI-GPM because rice fields were controlled ventilation and not abused in the use of inorganic fertilizers, especially nitrogen fertilizer. 
- Biodiversity: The model of semi-aquatic (rice) - terrestrial (potato) helped to kill common weed seeds and reduced their impact on the spring rice crop. However, the SRI-GPM was not only beneficial but also contributing to ensuring biodiversity in the cultivation process. SRI-GPM showed the increase of the land use coefficient from 2 crops to 3 crops per year and adding other plants which does not belong to Poaceae family by alternating a terrestrial crop - potato (Solanaceae). At the same time, the application of SRI-GPM, which does not use herbicides, enhanced the diversity of grass species. This advantage was very beneficial to rice because of the increased grass diversity. However, the nutritional and light competition of weeds for ricedecreased because it limited the dominance of some major weeds competing with rice such as Echinochloa crus-galli L., Leptochloa chinensis L., Monochoria vaginnalis burm F.. On the other hand, the conversion of herbage from spraying to weeding and stirring the mud did not affect the diversity in rice field but increased the number of insect species facilitated many natural enemies (like bees. spiders...) and beneficial microorganisms for growing rice [12].

\subsubsection{Changing people's awareness about environmental protection and climate change}

\section{- Change in use of straws}

Straws has proven its potential in various use forms such as for sale, organic fertilizer, fungus cultivation, foods for cattle, etc. However, there were still many people wasting this valuable material resource. In the past, farmers were willing to abandon straw at the field (20.7\%), or drying to make food for cattle $(22.2 \%)$, and they were not even interested in collecting to take advantage of straw, but instead $57.1 \%$ of people chose to burn straw. However, after project, villagers gained more knowledge to utilize straw there were biggest change as $77.8 \%$ of households chose collect straw to incubate for potatoes (Figure 1).

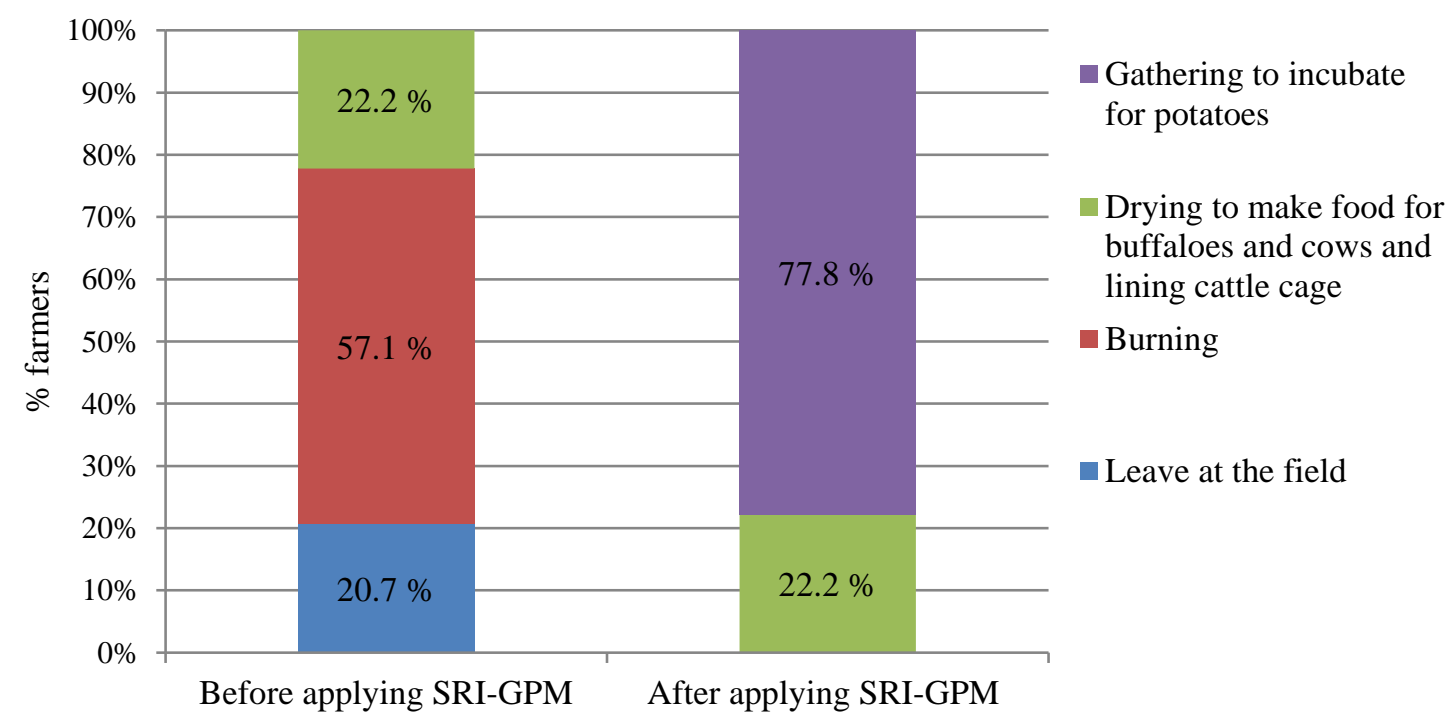

Figure 1. Change in farmer's use of rice straw

- Changes in the use of pesticides and fertilizers

Application of the SRI-GPM reduced the use of pesticides for rice. The research results suggest that before the study implemented, people were over-reliant on pesticides, with $44 \%$ farmers spraying 3 times and $37.7 \%$ more than three times. However, after the project, people abandoned the habit of pesticide use; most people only sprayed insecticide twice (up to 55\%). Farmers had habit of throwing empty pack of pesticides into the environment, but when the study ended, percent of households putting pesticide package in the waste bins increased $62.3 \%$ 
(previously only $22.3 \%$ of households). The application of the SRI-GPM minimized the impact on the environment by changing the way farmers used fertilizers. The amount of manure and chemical fertilizer used in applying the SRI-GPM was significantly lower than that of CRM; particularly manure reduced 3.5 tons/ha, and chemical fertilizers including nitrogenous fertilizer, phosphate fertilizer and potassium fertilizer decreased $92.3 \mathrm{~kg} / \mathrm{ha}, 127.9 \mathrm{~kg} / \mathrm{ha}$ and $27.8 \mathrm{~kg} / \mathrm{ha}$, respectively (Table 4).

Table 4. Use fertilizer for spring rice crop in 2019

\begin{tabular}{lcccc}
\hline & $\begin{array}{c}\text { Manure } \\
\text { (tons/ha) }\end{array}$ & Nitrogen & Phosphate & Potassium \\
\cline { 3 - 5 } & 7.7 & 147.3 & 339.2 & 111.2 \\
\hline Traditional & 4.2 & 55.6 & 211.3 & 83.4 \\
SRI-GPM & -3.5 & -92.3 & -127.9 & -27.8 \\
$(+/-)$ & & &
\end{tabular}

- Causes of environmental pollution

After adopting the SRI-GPM model, farmers had made changes in waste treatment. With organic waste, farmers had made use of compost $(21.5 \%)$ as compared to traditional ones. However, most farmers still chose to use organic waste for cattle feed $(83 \%)$, and only one fraction of the farmers, who threw out the garden or mixed with inorganic waste, brought to the public garbage pit $(6.5 \%)$. Similarly, to inorganic waste treatment, SRI-GPM had a very positive effect on farmers' inorganic waste treatment practices. As a matter of fact, no household would throw away waste or burn it, instead 52.5\% of households chose to put in the public bins and $47.5 \%$ of households collected them for sale (Table 5).

Table 5. Farmer's practice in waste disposal (\% household)

\begin{tabular}{lccc}
\hline \multicolumn{1}{c}{ Organic waste } & Traditional & SRI-GPM & $(+/-)$ \\
\hline - Make food for cattle & 83.0 & 83.0 & 0.0 \\
- Throw out the garden or mix with inorganic & 27.0 & 6.5 & -21.5 \\
waste brought to the public garbage pit & 0.0 & 21.5 & +21.5 \\
- Composting materials & & & -69.6 \\
\hline \multicolumn{1}{c}{ Inorganic waste } & 69.6 & 0.0 & +37.9 \\
\hline - Throw away or burn & 14.6 & 52.5 & +31.7 \\
- Thrown in public trash & 15.8 & 47.5 & \\
- Collect for sale & & & \\
\hline
\end{tabular}

- Change in farmer's perceptions of environmental issuess

Currently, environmental pollution, greenhouse gas emissions such as $\mathrm{CH}_{4}, \mathrm{CO}_{2}, \mathrm{~N}_{2} \mathrm{O}$ and climate change were priority issues in the world. With a desire to minimizing the impact of environmental pollution and limiting greenhouse gas emissions, it is important to change farmer's awareness on the environment issues.

Table 6. Change in farmer's perceptions of environmental issues (\% farmers)

\begin{tabular}{lccc}
\hline \multicolumn{1}{c}{ Farmers' concerns } & $\begin{array}{c}\text { Before applying } \\
\text { SRI-GPM }\end{array}$ & $\begin{array}{c}\text { After applying } \\
\text { SRI-GPM }\end{array}$ & $\begin{array}{c}\text { Increase / } \\
\text { decrease (+/-) }\end{array}$ \\
\hline Paying attention to environmental pollution & 32.2 & 80.4 & +48.2 \\
Concerned about climate change & 7.1 & 61.6 & +54.5 \\
Understanding of greenhouse gas emissions & 0.0 & 16.2 & +16.2 \\
\hline
\end{tabular}


As shown in Table 6, after the SRI-GPM model applied, farmers were more concern about climate change, it has increased $54.5 \%$ compared to the previous and the attention of farmers to the environment pollution also has a positive change, it increased by $48.2 \%$ compared to the previous. It is notable that in the absence of the SRI-GPM model, no farmer has knowledge on greenhouse gas emissions. However, after the model applied, $16.2 \%$ of farmers have an understanding of greenhouse gas emissions. It can be argued that the application of the SRI-GPM model has not only changes the rice farming method but also changes the farmer's awareness of the environment and climate change. This could be an important momentum for the development of a larger-scale SRI-GPM model in the future.

\subsection{Social impact and policy linkages}

Applying the SRI-GPM encouraged farmer participation in group activities through FFS classes. As a result of working in group farmers helped each other transplanting rice in time and sharing experiences. Working together helped them to understand each other to create confidence in the building of effective agricultural cooperatives in the future.

The SRI-GPM model provided opportunities for the development of linkages and partnerships between the four partners: farmers - private sector - scientists - government. The conversion from CRM to SRI-GPM created opportunities for cooperation with enterprises, and implemented the policy of linkage of 4 partners. The Thai Nguyen Seed Center signed a cooperation contract with farmer's group to invest 50 ha of Bao Thai rice with SRI application in summer rice crop of 2019; Que Lam Company invested in organic rice production with an area of 80 ha in both Spring and Summer rice crops of 2019; Thien Nong Phat Company committed to invest in producing 30 ha of winter potato in 2019 with group of farmers. The model also received provincial and district support for organic production such as seed and fertilizer support for area of commodity production. On the other hand, the commune authorities encouraged the conversion of production from monoculture towards the production of commodities and organic products, and formation of production groups and agricultural service cooperatives. Agricultural and Service Cooperative No.1 was established in Tan Duc commune.

\subsection{Prospective of SRI - GPM and the conversion of rice cultivation towards ecological agriculture}

Table 7. If applying most of SRI principles and GPM techniques \& contracting with enterprises

\begin{tabular}{|c|c|c|c|c|}
\hline \multicolumn{5}{|c|}{ Unit: thousand VND } \\
\hline \multicolumn{2}{|r|}{ Content } & Control & SRI & SRI-GPM \\
\hline \multirow{2}{*}{\multicolumn{2}{|c|}{$\begin{array}{l}\text { Revenue } \\
\%\end{array}$}} & $73,234.5$ & $88,666.0$ & 268,513.1 \\
\hline & & 100.0 & 121.1 & 366.6 \\
\hline- & Rice & $73,234.5$ & $88,666.0$ & $93,513.1$ \\
\hline- & Potatoes & & & 175.000 .0 \\
\hline \multirow{2}{*}{\multicolumn{2}{|c|}{$\begin{array}{l}\text { Expenditure } \\
\%\end{array}$}} & $68,330.9$ & $65,190.1$ & $127,260.2$ \\
\hline & & 100.0 & 95.4 & 168.2 \\
\hline- & Materials & $52,779.7$ & $49,638.9$ & $80,606.6$ \\
\hline - & Labor & $15,551.2$ & $15,551.2$ & $46,653.6$ \\
\hline \multicolumn{2}{|c|}{ Revenue - Expenditure } & $4,903.6$ & $23,476.0$ & $141,252.9$ \\
\hline \multicolumn{2}{|c|}{$\%$} & 100.0 & 479.0 & $2,881.0$ \\
\hline \multicolumn{2}{|c|}{ Efficiency of labor investment (thousand VND/man-day) } & 210.5 & 401.5 & 644.4 \\
\hline \multicolumn{2}{|c|}{ Efficiency capital investment (VND/VND) } & 1.09 & 1.47 & 2.75 \\
\hline
\end{tabular}

Since the SRI-GPM was implemented in the farmer's fields with the practical conditions of the farmers and was also deployed at the first time, the model encountered difficulties such as not following the potatoes and rice cultivation technique procedure, and the potatoes variety did not guarantee quality; which led to a 7\% increase in SRI yield for rice while the potato yield was 
only 18 tons/ha (66\% of the annual average). Meanwhile, the results of this research and application of SRI in Thai Nguyen and other provinces showed that rice yield increased from 13 to $29 \%$; yield of potato was from 25 to 30 tons/ha [4]. This greatly affected the value of labor and capital investment efficiency.

Assuming that all the SRI principles were applied rice yield would only increase by $15 \%$, the potatoes variety had good quality compliance with the technical procedure and potatoes yield reaching 25 tons/ha, and farmers cooperated with enterprises (enterprises pay 7,000 VND/kg of potatoes, compared to $6,500 \mathrm{VND} / \mathrm{kg}$ and price of rice increased by $10 \%$ as agreed by the Seed Center) would increase the income to 141.2 million VND/ha, 644.4 thousand VND/labor-day and 2.75 VND/kg for the investment capital in cultivation in SRI-GPM, respectively (Table 7).

\subsection{Change of rice cultivation towards sustainable ecological agriculture}

The model increased the added-value, ensuring the economic target and a stable and sustainable production. It is necessary to plan the production area of rice and potato rotary; develop a system of facilities, especially irrigation and drainage systems, field-inland paths for goods production and mechanization; and promote mechanization in production. Organization of production in groups with strict supervision is necessary to ensure quality, applying the right process for commodities such as SRI rice and GPM potato. The use of straw in potato cultivation should be encouraged to limit the incineration of straw. The cooperation with companies whould be enhanced to have the farmers join deeply into the value chain to increase income. The model with potatoes or other crops should be built up and replicated so that people can see the advantages of ecological agriculture, and therefore change their perceptions and actions. The role of the government should be strengthened and supporting policies such as direct and targeted support, should be adopted and focus on changing the structure of crops towards the direction of ecological agriculture.

\section{Conclusion}

The study compared three farming practices (CRM, SRI and SRI-GPM). The SRI-GPM exploited the potential advantages of the locality, a purely agricultural place that mainly produces rice; it changed the farming practice of rice monoculture to rotational crops with plants in the direction of commodity production, thereby increased productivity, efficiency of labor and capital investment, and income for farmers. Applying SRI-GPM created an ecological balance, reducing greenhouse gas emissions, helping people raise awareness about environmental protection and responding to climate change. SRI-GPM has been developed on the farmers' fields, with the real conditions of the farmers; organized, monitored and evaluated by the farmers so that it has increased the awareness of active participation; social relationship in the rural community. SRI-GPM has created a cooperative connection between farmers, private sectors, scientists and government, creating opportunities for farmers to participate in the value chain to increase high added value and stable for local people. The SRI-GPM is a practical example that forms the basis for the development of new policies that promote the conversion of rice monoculture farming towards sustainable agriculture.

\section{REFERENCES}

[1] V. P. Hoang, "The study on System of Rice Intensification (SRI) in Spring season, 2004 in Thai Nguyen," (in Vietnamese), Journal of Science \& Technology - Ministry of Agriculture and Rural Development, no. 53, pp. 40-43, 2005.

[2] V. P. Hoang, "The study on technical measures in the System of Rice Intensification (SRI) on rainfed land in Vo Nhai district, Thai Nguyen province," (in Vietnamese), Journal of Science \& Technology Ministry of Agriculture and Rural Development, no. 10, pp. 26-32, 2012.

[3] V. P. Hoang, N. Q. Nguyen and T. H. Nguyen, "The System of Rice Intensification (SRI): The scientific basis and approach of ecological agriculture," 2016. [Online]. Available: 
http://sri.ciifad.cornell.edu/countries/vietnam/vn_HVPhu_SRI_scientific_bases_and_ecoagriculture_a pproach0916.pdf. [Accessed Mar. 12, 2021].

[4] T. D. Ngo and V. P. Hoang, "System of Rice Intensification in Vietnam: A Decade Journey," presented at the event entitled The SRI Journey in Vietnam: A Decade On, Thai Nguyen, Vietnam, Sept. 27-28, 2016. [Online]. Available: https://vietnamsri.wordpress.com/2017/04/25/the-10-years-journey-of-sriin-vietnam/. [Accessed Mar. 18, 2021].

[5] T. T. A. Truong, J. Fry, P. V. Hoang, and H. H. Hoang, "Comparative energy and economic analyses of conventional and System of Rice Intensification (SRI) methods of rice production in Thai Nguyen Province, Vietnam," Paddy and Water Environment, Publisher Springer Japan, vol. 15, no. 4, pp. 931941, 2017.

[6] General Department of Crop Production, Decision No. 204/QD-TT-CLT, Technical package of growing potatoes using a minimally tillage method with straw covered, (in Vietnamese), May 28, 2013.

[7] M. R. Carter, D. Holmstrom, J. B. Sanderson, J. Ivany, and R. DeHaan, "Comparison of conservation with conventional tillage for potato production in Atlantic Canada: crop productivity, soil physical properties and weed control," Canadian Journal of Soil Science, vol. 85, pp. 453-461, 2005.

[8] S. Sadanandan, P. Natarajan, D. Antony, and V. P. Vipinkumar, "Data tools: Participatory Rural Appraisal Techniques," Cochin University of Science and Technology, 2007. [Online]. Available: http://eprints.cmfri.org.in/9894/1/Data_Tools_Participatory_Rural_Appraisal_Techniques.pdf. [Accessed Mar. 10, 2021].

[9] W. C. Philip, J. R. Bell and P. A. Cook, Practical Field Ecology: A Project Guide. John Wiley \& Sons Ltd. 2011, pp. 60-94.

[10]L. A. Ribera, F. M. Hons, and J. W. Richardson, “An Economic Comparison between Conventional and No-Tillage Farming Systems in Burleson County, Texas," Agronomy Journal, 2004. [Online]. Available: https://doi.org/10.2134/agronj2004.4150. [Accessed Mar. 19, 2021].

[11]C.H. Sijtsma, A. J. Campbell, N. B. McLaughlin, and M. R. Carter, "Comparative tillage costs for crop rotations utilizing minimum tillage on a farm scale," Soil and Tillage Research, vol. 49, no. 3, pp. 223231, 1998, doi: 10.1016/S0167-1987(98)00175-5.

[12]N. Uphoff, I. Anas, O. P. Rupela, A. K. Thakur, and T. M. Thyagarajan, "Learning about positive plant-microbial interactions from the system of rice intensification (SRI)," Aspect Applied Biology, vol. 98, pp. 29-54, 2009. 